\section{Magdalena Hułas}

Instytut Historii im. Tadeusza Manteuffla Polskiej Akademii Nauk Warszawa
BIAtOSTOCKIE

TEKl

HISTORYCZNE

TOM 15/2017

ISSN 1425-1930

DOI: $10.15290 /$ bth.2017.15.10

\title{
Wrogowie naszych sojuszników. Kwestia (nie)istnienia stanu wojny między Polską a Włochami. 1940
}

Celem niniejszych rozważań jest przedstawienie dylematu, przed jakim stanął rząd polski w związku ze spodziewanym, a następnie dokonanym, przystąpieniem Włoch do wojny po stronie III Rzeszy. Decyzja Włoch o wypowiedzeniu 10 czerwca 1940 r. wojny Francji i Wielkiej Brytanii stawiała władze RP w kłopotliwym położeniu. Z jednej strony Polska, związana z obydwoma demokracjami układami sojuszniczymi, zobowiązana była do konsultowania z nimi zakresu i sposobu udzielania sobie pomocy w przypadku agresji państwa trzeciego (innego niż Niemcy); z drugiej zaś angażowanie się w konflikt z Włochami nie leżało w interesie Polski. Poniżej przedstawione zostaną najważniejsze, w naszym pojęciu, elementy warunkujące stanowisko Polski wobec wejścia Włoch do wojny, stanowisko prowadzące do zgody na udział wojsk polskich w walkach przeciw Włochom.

Bezpośrednio po niemieckiej agresji na Polskę, 1 września 1939 r., Włochy zdecydowały się na nieuczestniczenie w wojnie i ogłosiły, iż znajdują się w stanie ,non belligeranza”. Informując o tym stronę polską Włosi dodawali, że nowa sytuacja nie spowoduje przerwania dostaw do Polski włoskiego sprzętu wojskowego zamówionego przed wybuchem wojny. Deklaracje te spotkały się z pozytywną oceną strony polskiej, odczytywano je nawet jako zapowiedź zmian polityki włoskiej w kierunku zbliżenia z demokracjami zachodnimi². Cieniem na wzajemnych relacjach położyła się wypowiedź Benito Mussoliniego z 23 września.

\footnotetext{
1 Za podstawę niniejszego artykułu posłużył referat wygłoszony przez autorkę na konferencji zorganizowanej przez Akademię Obrony Narodowej, w listopadzie 2011 r., „Tobruk 1941. 70. rocznica udziału Samodzielnej Brygady Strzelców Karpackich w obronie Tobruku”. Autorka składa podziękowanie anonimowemu recenzentowi artykułu za uwagi umożliwiające poprawienie pierwotnego tekstu.

2 K. Strzałka, Między przyjaźniq a wrogością. Z dziejów stosunków polsko-włoskich (19391945), Kraków 2001, s. 63-64.
} 
W przemówieniu wygłoszonym na spotkaniu z działaczami faszystowskimi z Bolonii, użył on określenia „La Polonia è liquidata”. Nie był to odosobniony przykład takiego widzenia sytuacji Polski. Po agresji radzieckiej z 17 września pojawiały się podobne wypowiedzi i innych włoskich polityków ${ }^{3}$, a także publicystów. W instrukcjach dla prasy pisano wręcz, ,że wojna na Zachodzie nie ma więcej sensu i celu, ponieważ Polska jest skończona «La Polonia e finita»"4. Sformułowania te odbierano po stronie polskiej negatywnie zarówno ze względów emocjonalnych, jak i prawnopolitycznych. W świetle dziejowych doświadczeń Polski, związanych z brakiem państwowości, zrozumiałe jest wyczulenie polskiej dyplomacji na tym punkcie. Słowa sugerujące, że Polska po raz kolejny utraciła państwowość godziły w podstawowe interesy RP. Ponadto, określenie użyte przez Mussoliniego współbrzmiało ze stanowiskiem (sprzecznym z zasadami prawa międzynarodowego) Związku Radzieckiego i Niemiec. Tym groźniejsze więc było dla interesów polskich.

Deklaracja Mussoliniego różniła się jednak od enuncjacji radzieckiej i niemieckiej tym, że nie pociągała za sobą skutków, jakie logicznie powinny z niej wynikać. Mimo oświadczenia o końcu państwa polskiego, Włochy utrzymywały z tym państwem stosunki dyplomatyczne. Wnosić stąd można, że mamy do czynienia z deklaracją o charakterze propagandowym, mającą pomóc w realizacji prowadzonej przez Duce polityki zmierzającej - jak sam to ujął - do zlokalizowania konfliktu. Być może właśnie ze względu na ten charakter oświadczenia stosunkowo łatwo było Mussoliniemu się z niego wycofać; znacznie łatwiej niż stronie polskiej puścić je w niepamięćs. Stosunki dyplomatyczne między obydwoma państwami nadal były utrzymywane - ambasador Pietro Arone di Valentino, mimo iż nie towarzyszył rządowi polskiemu we Francji, zachował tytuł ambasadora w Polsce do czerwca 1940 r. ${ }^{6}$, a Bolesław Wieniawa Długoszowski, mimo iż jego nazwisko nie

\footnotetext{
3 Przykładowo, ambasador włoski w Moskwie, Augusto Rosso, użył określenia „była Polska” (ex-Polonia). Zob.: A. Rosso do G. Ciano, 17.09.1939, I documenti diplomatici italiani. Serie 9 (1939-1943) [dalej: DDI 9], t. 1 (4 settembre - 24 ottobre 1939), Roma 1954, dok. 278, s. 173.

4 Cyt. za: K. Strzałka, op. cit., s. 76. Na temat ówczesnych włoskich koncepcji dotyczących przyszłości państwa polskiego ibidem, s. 99-114. Zob. też np.: Ciano’s Diplomatic Papers, ed.: M. Muggeridge, tłum. S. Hood, London 1948, s. 309-316 (rozmowa G. Ciano - A. Hitler, 1.10.1939) i ibidem, s. 321-327 (rozmowa G. Ciano - R. Ley, 6.12.1939).
}

5 O tym, jak głęboko zapadło to określenie w polskiej pamięci świadczy wpis gen. Klemensa Rudnickiego w księdze pamiątkowej w Predappio, miejscu urodzenia Mussoliniego: „Polonia non e liquidata. 27 października 194418 Lwowski Batalion Piechoty zdobył Predappio”. Za zwrócenie uwagi na ten fakt dziękuję dr. hab. Andrzejowi Krzysztofowi Kunertowi.

${ }_{6} \quad$ K. Strzałka, op. cit., s. 83. Pojawia się też informacja, że włoski ambasador, ,,[p]o powrocie do Rzymu podał się do dymisji stwierdzając, że «kariera ambasadora, którego misję kończy wojna, jest złamana»". J. Szembek, Diariusz, wrzesień - grudzień 1939, oprac. B. Grzeloński, Warszawa 1989, przyp. 3, s. 31. Arone di Valentino ewakuował się z Polski przez Krzemieniec, a następnie Rumunię. W Rzymie na pewno był już 27 września, wówczas bowiem zdawał relację Galeazzo 
figurowało w spisie dyplomatów akredytowanych przy Kwirynale opublikowanym w lutym 1940 r., również do czerwca 1940 r. pozostawał na swoim stanowisku.

Sytuacja taka odpowiadała rządowi polskiemu z kilku względów. Po pierwsze, jednym z ważniejszych jego celów było zapewnienie Polsce możliwie szerokiej reprezentacji dyplomatycznej. Wprawdzie rząd włoski postanowił nie odpowiadać na polską notyfikację o utworzeniu we Francji nowego rządu, ale fakt pozostawienia wzajemnych stosunków bez wprowadzania dramatycznych zmian był dla strony polskiej korzystny ${ }^{7}$. Po drugie, relacje między Polską i Włochami były tradycyjnie dobre, a w czasie trwającej już dziewięć miesięcy wojny Polacy doznawali od Włochów przychylnego traktowania. Z wdzięcznością były przyjmowane przez rząd RP przyjazne gesty wobec polskich uchodźców, a zwłaszcza wobec osób pragnących przedostać się do Francji, do reorganizowanego tam Wojska Polskiego ${ }^{8}$. Nie bez znaczenia dla stanowiska Włochów był fakt, że Wieniawa Długoszowski miał dobre osobiste stosunki z włoskim ministrem spraw zagranicznych Galeazzo Ciano. Po trzecie wreszcie, Polacy liczyli na polityczne wsparcie ze strony Włoch przy redagowaniu warunków pokoju po zakończonej wojnie, zwłaszcza w obliczu konfrontacji z ZSRR. ${ }^{9}$ Nadzieje te opierano przede wszystkim na ocenie dotychczasowej polityki Włoch jako fundamentalnie antykomunistycznej.

Ten ostatni element odgrywał rolę szczególną. Ilustracją takiego sposobu myślenia jest notatka przygotowana w Biurze Prac Politycznych w maju 1940 r. ${ }^{10}$

Ciano nt. swoich wrażeń z wojny w Polsce - G. Ciano, Dziennik. 1937-1943, tłum. i oprac. nauk. T. Wituch, Pułtusk 2006, s. 429-430.

7 Zob.: H. Batowski, Walka dyplomacji hitlerowskiej przeciw Polsce. 1939-1945, Kraków, Wrocław 1984, s. 39; J. Sobczak, Polska w propagandzie i polityce III Rzeszy w latach 1939-1945, Poznań 1988, s. $78 \mathrm{nn}$. Włoskie stanowisko wobec nowego rządu polskiego wiązało się z pewnymi ograniczeniami, na co wskazuje np. fakt, że ambasador włoski w Madrycie, Gaston Gambara, uzyskał zgodę na utrzymywanie z posłem polskim, Marianem Szumlakowskim, jedynie stosunków „prywatnych” (,,rapporti personali”). Zob.: G. Ciano do G. Gambara, 23.12.1939, DDI 9, t. 2 (25 ottobre - 31 dicembre 1939), Roma 1957, dok. 695, s. 540. Symptomatyczne jest również określenie użyte przez włoskiego chargé d'affaires w Londynie w jego raporcie na temat wizyty Augusta Zaleskiego w Wielkiej Brytanii w lutym 1940 r. Pisał on o Zaleskim jako o ministrze spraw zagranicznych polskiego rządu tymczasowego. Zob.: Fracassi do G. Ciano, 23.02.1940, DDI 9, t. 3 (1 ${ }^{\circ}$ gennaio - 8 aprile 1940), Roma 1959, dok. 368, s. 311-312, tu: 311.

8 Zob.: M. Romeyko, Wspomnienia o Wieniawie i o rzymskich czasach, Warszawa 1990, s. 180 nn.; S. Sierpowski, Stosunki polsko-włoskie w latach 1918-1940, Warszawa 1975, s. 613 nn.; idem, Italy and the Nazi Aggression on Poland in 1939, „Polish Western Affairs” 1978, t. 19, nr 1, s. 34-57, tu: 54-56; J. Sobczak, op. cit., s. 142-144; K. Strzałka, op. cit., s. 168 nn.

9 Strona włoska utwierdzała Polaków w tym przeświadczeniu, co ilustrują słowa włoskiego posła w Bernie, Attilio Tamaro: „Mussolini będzie mógł oddać jeszcze Polsce wielkie usługi przy definitywnym regulowaniu stosunków w Europie" - raport A. Ładosia, 7.06.1940, Archiwum Akt Nowych, Warszawa (dalej: AAN), Poselstwo w Bernie, 6, k. 25-28, tu: k. 26.

10 „Notatka w sprawie przygotowania drogą propagandy polskiego programu terytorialnego", 6.05.1940, Polskie Dokumenty Dyplomatyczne. 1940, red. M. Hułas, Warszawa 2010 (dalej: PDD 1940), dok. 214, s. 370-372. 
Fragment tego dokumentu, mówiący o „,podstawach ideologicznych wojny”, sugerował odejście od stosowanego przez aliancką propagandę przeciwstawienia demokracji ustrojom „totalistycznym” (takiego określenia wówczas używano). Proponowano w zamian, by istotę toczącej się wojny przedstawiać jako walkę „kultury zachodniej opartej na etyce chrześcijańskiej i prawie rzymskim z nawrotem do barbarzyństwa i poganizmu" ${ }^{11}$. Według autorów dokumentu pierwsze z tych przyrównań „stawia automatycznie Włochy po stronie naszych wrogów”, drugie natomiast ,dąży do stworzenia wspólnego frontu ideologicznego całego świata cywilizowanego, a więc z włączeniem Włoch, przeciw Niemcom i Rosji”. Przewidywano, iż w razie utworzenia bloku niemiecko-radziecko-włoskiego alianci będą dążyć do jego rozbicia, co postawi ich przed alternatywą: albo ustępstwa wobec ZSRR i walka do końca przeciw Włochom, albo próba przeciągania Włoch na swoją stronę i walka z ZSRR. W pierwszym przypadku - jak oceniano - koncesje na rzecz ZSRR przyznawane byłyby kosztem Polski. W związku z tym stwierdzano, że rozwiązaniem, które Polska powinna popierać, jest rozwiązanie drugie.

Ten sposób rozumowania bliski był politykom polskim w Londynie, chociaż naturalnie - w różnych kręgach zyskiwał różny stopień poparcia. Dokumenty zdają się wskazywać na to, że zwolennikiem utrzymania poprawnych stosunków z Włochami był minister spraw zagranicznych August Zaleski i jego otoczenie, podczas gdy premier Władysław Sikorski opowiadał się za bardziej zdecydowanym współdziałaniem z Brytyjczykami, co stawiało Włochów w gronie przeciwników, a nie potencjalnych sojuszników.

Włosi - co oczywiste - również byli zainteresowani tym, jaką decyzję podejmie rząd polski. W ich interesie leżało ograniczenie liczby państw wrogich w otwierającym się konflikcie. W Bernie 5 czerwca 1940 r. doszło do spotkania polskiego chargé d'affaires w Szwajcarii, Aleksandra Ladosia z włoskim posłem tamże, Attilio Tamaro. Przedmiotem rozmowy dyplomatów było spodziewane i jak twierdził Tamaro - już przesądzone przystąpienie Włoch do wojny, do którego rzeczywiście doszło pięć dni później. Włoski dyplomata tłumaczył tę decyzję z jednej strony koniecznością niedopuszczenia - w przypadku klęski Niemiec - do bolszewizacji Europy, z drugiej strony koniecznością uniknięcia sytuacji, w której Niemcy zwyciężyłyby same. Wyrażał żal, że Polska i Włochy znajdą się w przeciwnych obozach oraz nadzieję, że „, żadnym razie armia polska nie znajdzie się na froncie włoskim”. Najwyraźniej ten problem był istotny dla strony włoskiej, skoro Tamaro na zakończenie rozmowy powrócił do sprawy i stwierdził, że przywiązuje „wielką wagę [...] do tego, aby między Polską a Włochami nie było krwi przelanej”. Późniejszy rozwój wydarzeń wykazał, że i dla strony polskiej była to ważna kwestia, tymczasem jednak Ładoś stwierdził tylko, że sposób użycia armii polskiej jest

\footnotetext{
11 Podobne sformułowania pojawiły się już w okólniku A. Zaleskiego, 19.02.1940, PDD 1940, dok.
} 86, s. 145 . 
sprawą naczelnego dowództwa, a on sam nie jest upoważniony do składania na ten temat żadnych oświadczeń. Odniósł się jednak do wątku zasadniczego rozmowy, czyli włoskiej decyzji przystąpienia do wojny, i stwierdził, że „znacznie większą gwarancją zapobieżenia bolszewizacji Europy byłaby nietknięta siła Włoch przy końcu konfliktu, aniżeli wejście ich do wojny obecnie po stronie Niemiec"12.

Tego samego dnia, gdy Ładoś słał do centrali obszerny raport z rozmowy, Wieniawa wysyłał raport z Rzymu, w nieco innym świetle przedstawiający politykę Włoch. Ambasador przy Kwirynale odnotowywał niepożądaną z polskiego punktu widzenia poprawę stosunków włosko-radzieckich i jednoczesne ostudzenie relacji Włoch do Polski, czego przejawem było zwiększanie restrykcji wobec przebywających we Włoszech Polaków, w tym m.in. wydanie zakazu „opuszczania terytorjum Włoch Polakom zdolnym do służby wojskowej"13.

Sytuacja dojrzewała do podjęcia decyzji. Na posiedzeniu Rady Ministrów 8 czerwca dyskutowano nad tym problemem i, na wniosek Zaleskiego, postanowiono, że w przypadku wystąpienia Włoch przeciwko Francji i Wielkiej Brytanii ambasador RP zostanie z Rzymu odwołany. Jednak już wówczas podkreślano, że decyzja taka nie byłaby równoznaczna z decyzją o wypowiedzeniu wojny Włochom. Stwierdzono, że Polska nie miałaby obowiązku wypowiedzenia wojny, zwolniona bowiem była z niego ,zgodnie z analogią wytworzoną niewypowiedzeniem wojny Sowietom przez sprzymierzeńców"14.

Po wypowiedzeniu przez Włochy wojny Francji i Wielkiej Brytanii ambasador Długoszowski, zgodnie z instrukcją, opuścił Rzym ${ }^{15}$. August Zaleski, w okólniku do polskich placówek dyplomatycznych, informował o tej decyzji i o tym, że „Rząd Polski nie uważa się za będącego w stanie wojny z Włochami”. (Na marginesie warto zaznaczyć, że o fakcie tym nie został poinformowany dowódca Brygady Strzelców Karpackich, płk Stanisław Kopański $\left.{ }^{16}\right)$. Równocześnie Zaleski

\footnotetext{
12 Raport A. Ładosia, 7.06.1940 - por. przyp. 9. Zob. też: telegram A. Ładosia, 5.06.1940, informujący o spotkaniu, PDD 1940, dok. 262, s. 440-441.

13 Raport B. Wieniawy Długoszowskiego, 7.06.1940 - Instytut Polski i Muzeum im. Generała Sikorskiego, Londyn (dalej: IPMS), Ambasada R.P. w Londynie, A.12.3/2, k. 154-157 (tu: 157). Wieniawa już wcześniej informował Centralę o trudnej sytuacji placówki w Rzymie. 21.03.1940 pisał: „Włochy nie są krajem neutralnym, lecz sprzymierzeńcami Niemiec [...] Ambasada nasza tutaj jest tolerowana z licznych i rozmaitych powodów (nie wykluczając nawet osobistych), jest tolerowana 'na wszelki wypadek', ale tylko tolerowana, mimo wszystkich szeptanych wyrazów sympatii." (PDD 1940, dok. 146, s. 247)

14 Protokoły z posiedzeń Rady Ministrów Rzeczypospolitej Polskiej, t. I: październik 1939 - czerwiec 1940, oprac. W. Rojek, współpr. A. Suchcitz, Kraków 1994, s. 316.

15 Ambasador wyjechał z Rzymu 13 czerwca. Zob.: raport B. Wieniawy Długoszowskiego, 5.07.1940, PDD 1940, dok. 303, s. 487-491.

16 W depeszy do W. Sikorskiego, 21.06.1940, stwierdzał, że nie wie, czy Polska jest w stanie wojny z Włochami - treść depeszy przekazana przez Guy’a Salisbury-Jonesa do War Office, 21.06.1940, The National Archives, Kew (dalej: TNA), FO 371/24482, C 7570/7570/55. Zob. też: S. Kopański,
} 
wyjaśniał, że „[s]ytuacja jest analogiczna do sytuacji aliantów wobec Rosji Sowieckiej" ${ }^{17}$. Analogia ta będzie jeszcze wielokrotnie przywoływana, należy więc przyjrzeć się jej bliżej, a zwłaszcza spróbować rozeznać powody, dla których przywiązywano do niej tak duże znaczenie i rozstrzygnąć, czy obydwie sytuacje były rzeczywiście porównywalne.

Pierwsza z nich, tj. sytuacja powstała po radzieckiej agresji na Polskę, nie jest jednoznaczna pod względem formalnym. Wśród wydawanych przez stronę polską 17 września 1939 r., i bezpośrednio po tym dniu, deklaracji i oświadczeń nie ma żadnego dokumentu, w którym by stwierdzano, że zaistniał między Polską a ZSRR stan wojny. Była mowa o jednostronnym pogwałceniu polsko-radzieckiego układu o nieagresji, o inwazji, o napaści, ale nie było mowy o wojnie. Również Związek Radziecki nie złożył deklaracji o istnieniu stanu wojny z Polską, bowiem - jak już wspomniano - według niego państwo polskie przestało istnieć ${ }^{18}$. Tym samym nie został spełniony warunek, o którym mówi konwencja haska z 1907 r. w sekcji III poświęconej problemowi rozpoczynania działań wojennych. Jej artykuł 2 głosi: „Stan wojny powinien być mocarstwom neutralnym bez zwłoki zakomunikowany..." ${ }^{19}$. Wprawdzie dalsza część mówi o tym, że: "Wszakże nie mogą neutralne państwa powoływać się na nieotrzymanie tego zawiadomienia, jeżeli było ustalone w sposób niewątpliwy, że o stanie wojny istotnie wiedziały", ale w przypadku sytuacji polsko-radzieckiej trudno mówić o tym, żeby była ona ustalona " w sposób niewątpliwy".

Na temat problemów wynikających z nieogłoszenia w stosownym czasie stanu wojny między Polską a ZSRR mówił sekretarz generalny MSZ Zygmunt Graliński w trakcie posiedzenia Rady Narodowej 16 kwietnia 1940 r. w Angers. Stwierdził wówczas:

We wszystkich naszych oświadczeniach stoimy na stanowisku, że mamy stan wojny pomiędzy Polską a ZSRR i te rzeczy stawiamy zupełnie wyraźnie, pomimo, że zdajemy sobie sprawę, iż pomiędzy nami a aliantami istnieją jakby dwa oblicza w stosunku do Rosji i w stosunku do Niemiec. Jeżeli chodzi bowiem

Wspomnienia wojenne 1939-1946, Londyn b.d.w., s. 113 i H. Batowski, Rozmowy dyplomatyczne wokót Brygady Karpackiej latem 1940 roku, „Wojskowy Przegląd Historyczny”, 1981, nr 4, s. 231240, tu: 231.

17 Okólnik A. Zaleskiego, 12.06.1940, PDD 1940, dok. 274, s. 456. Zob. też: Documenti per la storia delle relazioni italo-polacche (1918-1940). Dokumenty dotyczqce historii stosunków polsko-włoskich (1918-1940 r.), a cura di / oprac. przez: M. Di Simone, N. Eramo, A. Fiori, J. Stoch, t. II, [Roma] 1998, dok. 559, s. 1592.

18 W opinii Jerzego Łojka ,przez brak konkretnej deklaracji Rząd RP przyjął niejako konsekwencje oświadczenia Mołotowa, że "państwo polskie przestało istnieć»" - J. Łojek (L. Jerzewski), Agresja 17 września 1939. Studium aspektów politycznych, Warszawa 1990, s. 89.

19 Tekst wg „Dziennik Ustaw” 1927, nr 21, poz. 159 - http://dziennikustaw.gov.pl/DU/1927/s/21/159 [30.01.2017]. 
o Rosję - Polska znajduje się w stanie wojny, wtedy, kiedy w stanie neutralności w stosunku do Rosji znajdują się Anglia i Francja. Nie mamy w tej chwili możności wypowiedzieć wojny Rosji, po pierwsze, dlatego że stan działań wojennych obecnie nie istnieje, a po drugie, gdybyśmy to zrobili teraz, to tym samym uznalibyśmy moment ogłoszenia takiej deklaracji za moment zaczęcia stanu wojennego, kiedy w naszym rozumieniu nastąpił on 17 września $^{20}$.

$\mathrm{Z}$ punktu widzenia rozpatrywanego problemu, tj. podobieństwa sytuacji niewypowiedzenia wojny przez Wielką Brytanię i Francję Związkowi Radzieckiemu w 1939 r. oraz przez Polskę Włochom w 1940 r., należy podkreślić, że w pierwszym przypadku mogły powstać formalne wątpliwości, czy sojusznik (Polska) jest w stanie wojny z innym państwem (ZSRR), podczas gdy w drugim ich nie było (zarówno Wielka Brytania, jak i Francja bez wątpienia były w stanie wojny z Włochami). Wystąpienie przeciwko państwu, z którym nasz sojusznik jest w stanie wojny (czyli odpowiednio przeciwko ZSRR i przeciwko Włochom), zgodnie z zawieranymi wcześniej układami, miało mieć miejsce po uprzednich wzajemnych konsultacjach. We wrześniu 1939 r. konsultacji takich, praktycznie rzecz biorąc, nie prowadzono. Rząd polski wystąpił wobec swoich sojuszników z notą, w której domagał się od nich kategorycznego protestu przeciw radzieckiej agresji i dodawał, że rezerwuje sobie możliwość zażądania wypełnienia zobowiązań wynikających z obowiązujących układów ${ }^{21}$. W 1940 r., w sytuacji przewidywanego przystąpienia Włoch do wojny, konsultacje były prowadzone, a przynajmniej konsultacje dotyczące zachowania sojuszniczych dyplomatów w Rzymie. Pisał o tym Zaleski 27 maja w depeszy do Wieniawy Długoszowskiego. Wynikało z niej, że wprawdzie nie podjęto jeszcze żadnych decyzji, ale prawdopodobnie „będzie postanowione, że wszyscy Alianci zajmą jednakowe stanowisko"22. Oczekiwania rządu RP odbiegały jednak od stanowiska sojuszniczego. Strona polska rozważała możliwość pozostawienia Wieniawy w Rzymie lub wycofania go do Watykanu. Zdecydowana też była nie wypowiadać Włochom wojny.

Również strona włoska przyjęła, że nie jest w stanie wojny z Polską. Kwestia ta nie jest, niestety, poruszana w opublikowanych włoskich dokumentach dyplomatycznych ${ }^{23}$. Jak pisze jednak Krzysztof Strzałka, który przeprowadził wnikliwą

\footnotetext{
20 Stenogram z posiedzenia RN, 16.04.1940 - IPMS, Rada Narodowa A.5 11/11. Notabene, na takie posunięcie, czyli deklarację wojny mającą działać wstecz, zdecydował się Eduard Beneš 16.12.1941 (na ten temat zob.: K. Marek, Identity and Continuity of States in Public International Law, Genève 1954, s. 308-309).

$21 \quad$ Polskie Dokumenty Dyplomatyczne. 1939 wrzesień-grudzień, red.: W. Rojek, współpr.: P. Długołęcki, M. Konopka-Wichrowska, M. Przyłuska, Warszawa 2007 (dalej: PDD 1939/2), dok. 95, s. 95.

22 PDD 1940, dok. 248, s. 424.

23 DDI 9, t. 5 (11 giugno - 28 ottobre 1940), Roma 1965; DDI 9, t. 6 (29 ottobre 1940 - 23 aprile 1941), Roma 1986; DDI 9, t. 7 (24 aprile - 11 dicembre 1941), Roma 1987 - tomy uwzględniające
} 
kwerendę w archiwach włoskich, na takie stanowisko oficjalnych czynników wskazują niektóre dokumenty włoskie z lat 1940-1941 oraz fakt, że Polska nie pojawiała się w sporządzanych przez Palazzo Chigi wykazach państw, z którymi Włochy były w stanie wojny ${ }^{24}$.

Wskazują na to też dokumenty polskie, np. depesza posła w Atenach, Władysława Schwarzburg-Günthera na temat wiadomości przekazywanych przez Polaków przybywających z Włoch. Zgodnie z tymi informacjami władze włoskie „podkreśla[ły] nieistnienie stanu wojennego między Polską a Włochami”25. Do takiego stanowiska włoskiego odwoływał się również Roman Mazurkiewicz, konsul generalny w Rzymie, który po opuszczeniu placówki w czerwcu 1940 r. udał się, wraz z pozostałymi polskimi przedstawicielami dyplomatycznymi i konsularnymi we Włoszech, do Lizbony ${ }^{26}$. Przesłał on do Centrali notatkę, w której pisał, że „W opinji włoskiej ustalił się słuszny pogląd, że pomiędzy Polską a Włochami nie ma stanu wojny"27.

Sytuacja nabrała nowej dynamiki po kapitulacji Francji. Utrata jednego z dwóch głównych sojuszników, konieczność ewakuacji do Wielkiej Brytanii i zacieśnienia współpracy z tym aliantem znacząco wpłynęły na sytuację rządu polskiego i kształt polskiej polityki. Zmianie uległa też sytuacja militarna. Po upadku Francji Brygada Strzelców Karpackich, stacjonująca dotychczas w Syrii, francuskim terytorium mandatowym, została przeniesiona do Palestyny, co wzmogło niebezpieczeństwo zaangażowania jej w walki z Włochami. W związku z tym, August Zaleski spotkał się 29 czerwca z Aleksandrem Cadoganem, stałym podsekretarzem stanu w Foreign Office (FO). Miał wówczas stwierdzić, że gdyby okazało się to konieczne, rząd polski chętnie wypowie Włochom wojnę ${ }^{28}$. Jednocześnie jednak dawał do zrozumienia, że stronie polskiej zależałoby na tym, by ograniczyć możliwości zbrojnego starcia polsko-włoskiego. Do rozmowy tej nawiązano 11 lipca, w trakcie spotkania Zaleskiego z Williamem Strangiem, zastępcą podsekretarza

okres od wejścia Włoch do wojny z Francją i Wielką Brytanią do czasu rozpoczęcia walk oddziałów polskich z włoskimi.

24 K. Strzałka, op. cit., s. 186. Zob. też podsumowanie sytuacji w raporcie K. Papée (ambasadora RP przy Stolicy Apostolskiej), 29.07.1941, Polskie Dokumenty Dyplomatyczne. 1941, red. J. Tebinka, Warszawa 2013, dok. 201, s. 452-454.

25 W. Schwarzburg-Günther do MSZ, 24.07.1940 - Zintegrowany System Informacji Archiwalnej: Archiwum Akt Nowych, Archiwum Instytutu Hoovera, Ministerstwo Spraw Zagranicznych (dalej: ZoSIA, AAN, HI, MSZ), zespół 800/42/0/-/38, folder 13, skan 827, http://szukajwarchiwach. $\mathrm{pl} / 800 / 42 / 0 /-/ 38$ [26.11.2011].

26 Grupa ta przybyła do Lizbony 19.06.1940 (raport B. Wieniawy Długoszowskiego, 5.07.1940, PDD 1940, dok. 303, s. 490).

27 R. Mazurkiewicz do MSZ, 3.08.1940, ZoSIA, AAN, HI, MSZ, 800/42/0/-/38, folder 13, skany 824-826, http://szukajwarchiwach.pl/800/42/0/-/38 [26.11.2011].

28 Sprawozdanie A. Cadogana z rozmowy z A. Zaleskim, 29.06.1940 - TNA, FO 371/24482, C 7570/7570/55. Zob. też: H. Batowski, Rozmowy dyplomatyczne..., s. 232. 
stanu w FO. Strang stwierdził wówczas, że sprawą rządu polskiego jest ocena, czy fakt ewentualnego użycia polskich oddziałów do walki z Włochami wymagać będzie wypowiedzenia przez rząd RP wojny Włochom. Dodawał jednak, że w opinii rządu Jego Królewskiej Mości (JKM) sytuacja byłaby bardziej klarowna, gdyby doszło do takiej deklaracji. Zaleski zapowiedział, że przedyskutuje sprawę z gen. Sikorskim. Następnego dnia o wyniku tych konsultacji poinformowali Stranga ambasador Edward Raczyński i sekretarz generalny MSZ, Jan Ciechanowski. Według ich informacji Sikorski zadecydował, że Brygada Karpacka pozostaje pod komendą gen. Archibalda Wavella i może być przez niego użyta zgodnie z potrzebami, również - jeśli zajdzie taka konieczność - w walkach z Włochami. Nie poruszono natomiast $\mathrm{w}$ trakcie tej rozmowy problemu ewentualnej deklaracji wojny między Polską a Włochami ${ }^{29}$.

Kapitulacja Francji i późniejsze wydarzenia odbiły się również na polskiej sytuacji wewnętrznej - zaostrzyły się spory, spolaryzowały stanowiska. Ewidentnym tego przejawem było odwołanie 18 lipca 1940 r. gen. Sikorskiego ze stanowiska premiera i powołanie w jego miejsce Augusta Zaleskiego. Kryzys został wprawdzie zażegnany, ale pogłębił pęknięcie na linii premier - minister spraw zagranicznych. Coraz wyraźniej zaznaczała się różnica w poglądach obydwu polityków na temat kierunków polityki zagranicznej i sposobów ich realizacji. Dotyczyło to zwłaszcza stanowiska wobec ZSRR. Sikorski był skłonny do prowadzenia bardziej pojednawczej polityki, podczas gdy Zaleski pozostawał w swoim podejściu nieprzejednany. Te różne punkty widzenia zostały wzmocnione przez zmieniającą się sytuację w Europie. Przypomnijmy: 14 i 17 czerwca dochodzi do zajęcia Estonii, Litwy i Łotwy przez ZSRR, 27 czerwca Związek Radziecki wystosowuje wobec Rumunii ultimatum w sprawie Besarabii i Północnej Bukowiny, od pierwszych dni lipca krążą pogłoski o planach przekazania przez Niemcy części Generalnego Gubernatorstwa Związkowi Radzieckiemu, 23 lipca Sumner Welles, amerykański podsekretarz stanu, wydaje deklarację potępiającą radzieckie zajęcie państw bałtyckich i odmawiającą uznania legalności tych aneksji.

W takich właśnie okolicznościach, 29 lipca, Zaleski stwierdził na posiedzeniu Rady Narodowej, że Polska uważa się za będącą w stanie wojny ze Związkiem Radzieckim, nie jest jednak w stanie wojny z Włochami, mimo iż zmuszona była

\footnotetext{
29 Sprawozdanie W. Stranga z rozmów z A. Zaleskim (11.07.1940) oraz E. Raczyńskim i J. Ciechanowskim (12.07.1940), 12.07.1940 - TNA, FO 371/24482, C 7570/7570/55. Na temat polsko-brytyjskich rozmów w sprawie użycia Brygady Karpackiej zob. też: H. Batowski, Rozmowy dyplomtyczne....; idem, Z dziejów dyplomacji polskiej na obczyźnie (wrzesień 1939 - lipiec 1941), Kraków, Wrocław 1984, s. 180 nn.; J. Tebinka, ,Wielka Brytania dotrzyma lojalnie swojego stowa”. Winston S. Churchill a Polska, Warszawa 2013, s. 50 nn.; idem, Churchill i Sikorski. Koncepcje wykorzystania Polskich Sit Zbrojnych w latach 1940-1941, [w:] Samodzielna Brygada Strzelców Karpackich w obronie Tobruku, red. nauk. J. Zuziak, Warszawa 2016, s. 123-136.
} 
do zerwania z nimi stosunków dyplomatycznych ${ }^{30}$. Wydaje się, że minister chciał w ten sposób wzmocnić polską pozycję, przypominając, że i Polska znajduje się wśród państw dotkniętych radziecką ekspansją. Nie jest wykluczone, że liczył na to, iż w obronie polskich terytoriów zajętych przez ZSRR, a zwłaszcza Wileńszczyzny, będzie można się odwołać do deklaracji Wellesa, co notabene uczynił (miał uczynić? ${ }^{31}$ ) jeszcze tego samego dnia, w rozmowie z lordem Halifaksem, brytyjskim ministrem spraw zagranicznych. O rozmowę tę prosił Zaleski, a bezpośrednim impulsem była być może narada, jaką poprzedniego dnia, tj. 28 lipca wieczorem, prezydent Władysław Raczkiewicz miał z gen. Kazimierzem Sosnkowskim, "jako zastępcą nieobecnego premiera", i właśnie z Zaleskim, w sprawie doniesień o planach przyłączenia GG do ZSRR. Prezydent przypominał „o niezłomności naszego stanowiska integralności granic Polski w stosunku do obydwu napastników" i stwierdził konieczność ponownego podkreślenia wobec Brytyjczyków tej podstawowej zasady polskiej polityki, bowiem - jak dodawał - „mamy prawo wymagać, by Anglia poparła w przyszłości to nasze stanowisko"32. Tak więc Zaleski (pod nieobecność Sikorskiego, który odbywał inspekcję polskich obozów wojskowych w Szkocji), zaniepokojony nowymi przejawami radziecko-niemieckiej współpracy we Wschodniej Europie, wyraził wobec brytyjskiego ministra spraw zagranicznych przekonanie o konieczności zajęcia stanowiska odnośnie do radzieckich posunięć w państwach bałtyckich. Zapowiedział też złożenie memorandum o współpracy radziecko-niemieckiej. W dokumencie tym polski minister przypominał, że rząd RP zgodził się w październiku 1939 r. pozostawić w zawieszeniu sprawę radzieckiej agresji na Polskę i traktować Niemcy jako wroga numer jeden. Zaznaczał jednak, że gdyby doszło do przejęcia przez ZSRR dalszych polskich terytoriów, wówczas Polacy niewątpliwie uznaliby Związek Radziecki za wroga równorzędnego $\mathrm{Niemcom}^{33}$.

Biorąc pod uwagę te okoliczności można przypuszczać, że poruszona przez Zaleskiego na posiedzeniu Rady Narodowej sprawa stosunku do Włoch była tylko

30 Przemówienie A. Zaleskiego, 29.07.1940, ZoSIA, AAN, HI, MSZ, 800/42/0/-/199, folder 16, skany 406-423, http://szukajwarchiwach.pl/800/42/0/-/199 [26.11.2011]; tłum. na ang.: ibidem, skany 424-433. Zob. też: TNA, FO 417/41, C 9088/7177/55. Szerzej nt. przemówienia zob.: P. Wandycz, Z Pitsudskim i Sikorskim. August Zaleski, minister spraw zagranicznych w latach 1926-1932 i 1939-1941, Warszawa 1999, s. 212-213.

31 W sprawozdaniu ze spotkania (PDD 1940, s. 540-542) nie ma mowy na ten temat, jest natomiast w notatce do rozmowy (Notatka do rozmowy A. Zaleskiego z Lordem Halifaksem, 29.07.1940 ZoSIA, AAN, HI, MSZ, 800/42/0/-/1, folder 11, skany 261-263). Do angielskiego sprawozdania z rozmowy nie miałam dostępu.

32 Dzienniki czynności Prezydenta RP Władysława Raczkiewicza. 1939-1947, t. I: 1939-1942, oprac. J. Piotrowski, Wrocław 2004, s. 215. Termin spotkania z Halifaksem uwzględniał też fakt, że 30 lipca miała się odbyć w Izbie Gmin debata nad problemem państw bałtyckich.

33 „Memorandum on the Soviet-German Partnership”, July 1940, confidential - ZoSIA, AAN, HI, MSZ, 800/42/0/-/1, folder 11, skany 264-271). 
pretekstem do przypomnienia pozycji Polski wobec ZSRR. Przemówienie ministra zostało opublikowane 31 lipca na łamach „Dziennika Polskiego” i wywołało szerokie reperkusje. Podczas posiedzenia Rady Ministrów 19 sierpnia Stanisław Stroński mówił o zaniepokojeniu brytyjskiej opinii publicznej tym wystąpieniem, zaniepokojeniu mającym wynikać z przypuszczeń, iż Polacy nie chcą walczyć z Włochami. Wszystko jednak wskazuje na to, że Brytyjczyków poruszyła nie tyle polska deklaracja o braku stanu wojny z Włochami, co oświadczenie o istnieniu takowego ze Związkiem Radzieckim. Również wielu Polaków krytykowało przemówienie Zaleskiego. Ministrowi zarzucano, że jego wystąpienie nie było uzgodnione z Radą Ministrów. Zaleski odpierał zarzuty i twierdził, że „,[p]rzemówienie to było całkowicie zgodnym z faktyczną i prawną sytuacją". Dla potwierdzenia tej zgodności dodawał, że „17 IX 1939 r. notyfikowaliśmy przez nasze przedstawicielstwa dyplomatyczne fakt napaści Sowietów na Polskę i równocześnie wydany został komunikat Rządu RP o zaistnieniu stanu wojny z Rosją. Tego nikt nie może kwestionować" ${ }^{34}$. Wbrew słowom Zaleskiego, w żadnym z przywołanych dokumentów nie ma mowy o stanie wojny między obydwoma państwami ${ }^{35}$.

Inną kwestią pozostaje sprawa nieuzgodnienia przemówienia z Radą Ministrów. Rzeczywiście, nie było ono uzgadniane, ale należy zwrócić uwagę na fakt, że dwa dni wcześniej Sikorski wystosował do Zaleskiego pismo ${ }^{36}$, w którym domagał się wzmożenia aktywności polskiej dyplomacji, w tym w sprawach związanych ze stanowiskiem wobec Włoch. Tę kwestię uznał premier za szczególnie istotną, ponieważ z jednej strony istniało duże prawdopodobieństwo konfrontacji militarnej Brygady Strzelców Karpackich z siłami włoskimi, z drugiej zaś - na co wskazywały powtarzające się pogłoski - możliwe było ponowne nawiązanie stosunków dyplomatycznych z Włochami. Sikorski podkreślał, że rozważając obydwa te przeciwstawne przypadki należy brać pod uwagę fakt, że celem nadrzędnym jest zachowanie zgodności polityki polskiej z polityką brytyjską.

Zatrzymajmy się nad problemem ewentualnego odnowienia polsko-włoskich stosunków dyplomatycznych. Informacje na ten temat są wyjątkowo skromne. Krzysztof Strzałka wspomina, że ,,jedynym znanym nam potwierdzeniem” faktu, iż inicjatywa w tym względzie należała do strony włoskiej ,jest wzmianka posła polskiego w Madrycie Mariana Szumlakowskiego, który miał telegrafować do podsekretarza stanu we włoskim MSZ Bastianiniego" w sprawie przybycia do

\footnotetext{
34 Protokoły posiedzeń Rady Ministrów Rzeczypospolitej Polskiej, t. II: czerwiec 1940 - czerwiec 1941, red. nauk. M. Zgórniak, oprac. W. Rojek, współpr. A. Suchcitz, Kraków 1995 (dalej: PPRM 2), s. 90.

35 PDD 1939/2, dok. 96, s. 95-96; dok. 95, s. 94-95; „Monitor Polski”, 25.09.1939, nr 213 (też: Documents on Soviet-Polish Relations, 1939-1945, t. 1: [1939-1943], London 1961, dok. 45, s. 47).

36 W. Sikorski do A. Zaleskiego, 27.07.1940, PDD 1940, dok. 323, s. 535.
} 
Rzymu polskiego przedstawiciela ${ }^{37}$. I rzeczywiście, chyba w Madrycie należy poszukiwać kluczy do tego zagadnienia.

Szumlakowski już wcześniej porozumiewał się z ministrem spraw zagranicznych w sprawie nieoficjalnych kontaktów z Włochami. W depeszy z 11 lipca pytał Zaleskiego, czy - wobec faktu, że Polska nie jest w stanie wojny z Włochami - wskazane jest nawiązanie przez niego kontaktu ,Z tutejszymi czynnikami włoskimi”" ${ }^{38}$. Wprawdzie Zaleski odpowiedział, że ,wobec możliwych komplikacji w naszych stosunkach z Włochami przez stosunek nasz do Anglii należy trzymać się z daleka od dyplomacji włoskiej"39, ale Szumlakowski prawdopodobnie kontakty takie nawiązał, skoro 23 lipca donosił, iż ma z ambasady włoskiej nieoficjalne informacje, ,że Włochy boleją nad zerwaniem jakoby przez nas stosunków dyplomatycznych i że pragnęłyby mieć w Rzymie przedstawiciela dyplomatycznego Polski” ${ }^{40}$. Zaleski w odpowiedzi upewniał się, czy „oferty włoskie są robione za zgodą Rzymu i czy jest pewność, że ewentualny protest niemiecki nie zmusi Włochów do ich cofnięcia" ${ }^{41}$.

Podobne informacje napływały do MSZ z Lizbony. Chodzi o cytowaną już wyżej notatkę wręczoną polskiemu posłowi w Madrycie, przesłaną przez Mazurkiewicza Zaleskiemu 3 sierpnia ${ }^{42}$. Najbardziej istotnym jej fragmentem był ten sugerujący ponowne nawiązanie stosunków włosko-polskich. Mowa w nim była o tym, że „wyrażano z wielu stron zdziwienie, że polska reprezentacja wyjechała [z Włoch - MH] w tak szybkim tempie i że nie pozostawiono ani jednej placówki konsularnej, któraby obok symbolizowania istnienia Polski mogła służyć jako łącznik pomiędzy czynnikami decydującymi obu krajów”. (,Jakie to strony? Taka informacja jest mało warta" - ktoś w MSZ dopisał na marginesie.) Według Mazurkiewicza Włosi skłonni byliby przyjąć w Rzymie ,jakiegoś znanego [sobie] wysokiego urzędnika MSZ” w charakterze ,,agenta dyplomatycznego”, jednak bez formalnego dyplomatycznego statusu. Mazurkiewicz uznawał również, że możliwe byłoby wznowienie we Włoszech działalności polskich placówek konsularnych, bowiem - zgodnie z posiadanymi przez niego informacjami - rząd włoski „nie unieważnił żadnym aktem urzędowym, wydanych swego czasu konsulom polskim 'exequatur'ów'.' Takie posunięcie wymagałoby jednak wcześniejszych nieoficjalnych rozmów przedstawicieli dyplomatycznych Polski i Włoch na terenie państwa neutralnego. Według Mazurkiewicza najbardziej odpowiednim miejscem negocjacji

\footnotetext{
37 K. Strzałka, op. cit., s. 211.

38 M. Szumlakowski do MSZ, 11.07.1940, ZoSIA, AAN, HI, MSZ, 800/42/0/-/38, folder 13, skan 834, http://szukajwarchiwach.pl/800/42/0/-/38 [26.11.2011].

39 A. Zaleski do M. Szumlakowskiego, 13.06.1940; ibidem, skan 833 [26.11.2011].

40 M. Szumlakowski do MSZ, 23.07.1940; ibidem, skan 832 [26.11.2011].

41 A. Zaleski do M. Szumlakowskiego, 1.08.1940; ibidem, skan 831 [26.11.2011].

42 Zob. przyp. 27.
} 
byłby Madryt, gdzie można byłoby dodatkowo liczyć na pośrednictwo hiszpańskie. W MSZ wyrażano co do tego wątpliwości (akapit o tym mówiący opatrzony został znakiem zapytania). Wątpliwości MSZ dotyczyły jednak przede wszystkim samych sygnałów jakoby płynących z Włoch. Do konsula Mazurkiewicza wysłano depeszę, w której proszono o sprecyzowanie, na ,jakie to koła zagraniczne (włoskie, neutralne, czy jakie)" powoływał się w swojej depeszy z 3 sierpnia ${ }^{43}$. Nie udało się odnaleźć odpowiedzi konsula, ale musiała być ona zachęcająca, skoro sprawa miała ciąg dalszy, jakim był wspomniany już wyżej kontakt posła Szumlakowskiego z podsekretarzem stanu we włoskim MSZ, Giuseppe Bastianinim, w sprawie ,przybyci[a] naszego delegata" ${ }^{4}$. Swego rodzaju pośrednią „odpowiedzią” na pytanie skierowane do Mazurkiewicza była depesza Szumlakowskiego, w której informował Centralę o dochodzących go prywatnie głosach ,z poważnych źródeł neutralnych” o tym, że „znalezienie choćby tymczasowego nieoficjalnego modus vivendi z urzędowymi czynnikami włoskimi byłoby pozytywnie przez Włochów przyjęte" ${ }^{45}$. W odpowiedzi Zaleski zalecił dyskretne zbadanie, czy poselstwo włoskie byłoby skłonne przeprowadzić takie negocjacje. Równocześnie wyrażał wątpliwość, czy Włochy mogłyby pozwolić sobie na taki wyraz niezależności w stosunku do Niemiec ${ }^{46}$. Tak czy inaczej sprawa upadła, w ocenie Szumlakowskiego, ze względu na zmianę polityki włoskiej wobec Polaków ${ }^{47}$.

Powracając do listu Sikorskiego do Zaleskiego z 27 lipca trzeba stwierdzić, że premier liczył na to, że w nowo powstałej sytuacji dyplomacja RP będzie mogła pełnić rolę pośrednika między stronami ${ }^{48}$. Z pisma Sikorskiego wynika też, że liczył on na pewnego rodzaju wzajemność. Wobec rozpoczętych negocjacji brytyjsko-radzieckich, stwierdzał, że „trzeba zrobić wszystko możliwe, by Anglia w swych rozmowach z Rosją liczyła się z naszą sprawą i naszym zdaniem, i odgrywała podobną rolę, jaką my chcieliśmy odegrać w jej stosunku do Włoch"49.

43 M. Potulicki do R. Mazurkiewicza, 20.08.1940 - ZoSIA, AAN, HI, MSZ, 800/42/0/-/38, folder 13, skan 823, http://szukajwarchiwach.pl/800/42/0/-/38 [26.11.2011].

44 Zob. K. Strzałka, op. cit., s. 211.

45 M. Szumlakowski do MSZ, 2.08.1940 - ZoSIA, AAN, HI, MSZ, 800/42/0/-/38, folder 13, skan 828, http://szukajwarchiwach.pl/800/42/0/-/38 [26.11.2011].

46 A. Zaleski do M. Szumlakowskiego, 7.08.1940; ibidem, skan 829 [26.11.2011].

47 Zob. K. Strzałka, op. cit., s. 212.

48 Brytyjczycy wysoko cenili informacje o sytuacji we Włoszech, otrzymywane od rządu polskiego (zob. np. opinię Orme Sargenta, zastępcy stałego podsekretarza stanu w FO przekazaną przez Franka Savery'ego, radcę w ambasadzie JKM przy władzach polskich - F. Savery do J. Ciechanowskiego [?], 22.12.1940, ZoSIA, AAN, HI, MSZ, 800/42/0/-/2, skan 113-114, http://szukajwarchiwach.pl/800/42/0/-/2, dostęp 26.11.2011). Jeszcze w styczniu $1941 \mathrm{r}$. wyrażali żal z powodu zamknięcia polskich placówek we Włoszech. Jak pisał 28 t.m. jeden z urzędników FO, spowodowało to odcięcie Brytyjczyków od wydajnych źródeł informacji zarówno o sytuacji w Rzymie, jak i o nastrojach panujących na prowincji - TNA, FO 371/26739, C 841/841/55.

49 W. Sikorski do A. Zaleskiego, 27.07.1940 - PDD 1940, dok. 323, s. 535. 
Tak więc, podczas gdy minister spraw zagranicznych podkreślał fakt istnienia stanu wojny między Polską a ZSRR, premier liczył na osiągnięcie celów polskiej polityki zagranicznej przy negocjacyjnym stole, z brytyjskim pośrednictwem. Mimo to, w czasie wspomnianego posiedzenia Rady Ministrów (19 sierpnia) Sikorski stwierdził, ,że nie ma żadnej różnicy pomiędzy nim a ministrem Zaleskim pod względem określenia stosunku do Rosji”. Dla pewności jednak ponownie dodawał, jak ważne jest pamiętanie o aspekcie brytyjskim. Myśl swoją precyzował jasno (i proroczo): „może kiedyś nastąpić porozumienie brytyjsko-sowieckie i [...] wówczas akcje nasze mogą znacznie spaść. Im silniej się przedtem zwiążemy z Wielką Brytanią, tym lepiej" ${ }^{50}$. I chociaż dodawał, że nie ma potrzeby wypowiadania Włochom wojny, to równocześnie przypominał słowa Mussoliniego o likwidacji Polski i podkreślał, że Włochy wystąpiły „z jawną agresją wobec naszych sprzymierzeńców". Przekonaniem Sikorskiego było, że Polska nie może zawieść zaufania Brytyjczyków i uchylać się od walki przeciwko Włochom. Ten punkt widzenia został zaakceptowany przez Radę Ministrów, która uchwaliła następującą deklarację: „Polska jest w sojuszu z W[ielką] Brytanią i zgodnie z tym armia polska walczy ramię w ramię z armią brytyjską wszędzie, gdzie zajdzie potrzeba" ${ }^{11}$.

Przypomnijmy, że było to 19 sierpnia. Zanim jednak doszło do tak jednoznacznej deklaracji szale wielokrotnie się wahały, zwłaszcza na przełomie lipca i sierpnia. Wiązało się to $\mathrm{z}$ jednej strony ze zbliżającym się terminem podpisania polsko-brytyjskiej umowy wojskowej, z drugiej - ze wzmożonym naciskiem władz brytyjskich na przesunięcie Brygady Strzelców Karpackich z Palestyny na front między Egiptem a włoską Libią.

W czasie negocjowania umowy wojskowej, podpisanej ostatecznie 5 sierpnia, strona polska zabiegała o to, by dołączony został do niej wspólny protokół stwierdzający, że oddziały polskie nie będą użyte przeciwko Włochom. Strona brytyjska nie godziła się na takie rozwiązanie, wobec czego Polacy wystąpili z propozycją, zgodnie z którą mieliby złożyć podczas podpisywania układu jednostronną i poufną deklarację następującej treści: „Polska nie będąc w stanie wojny z Włochami interpretuje ustęp I wstępu do układu [...] jako nie dotyczący akcji wojskowej Sił Polskich przeciwko Włochom" 52 . I takie rozwiązanie nie znalazło uznania Brytyjczyków. William Strang w rozmowie z ambasadorem Raczyńskim prosił 11 lipca, by strona polska zrezygnowała z zamiaru złożenia takiej deklaracji ${ }^{53}$. W rezultacie gen. Sikorski uznał, że brygada polska powinna pozostać pod komendą gen.

$50 \quad$ PPRM 2, s. 91.

51 Ibidem, s. 92.

52 Notatka E. Raczyńskiego, po 12.07.1940 - IPMS, Prezydium Rady Ministrów, PRM 20/8, k. 43-45 (tu: 43).

53 Notatka W. Stranga, 12.07.1940 - TNA, FO 371/24482, C 7570/7570/55. 
Archibalda Percivala Wavella, który mógł jej użyć stosownie do konieczności ${ }^{54}$, a Brytyjczycy zgodzili się na ,przyjęcie do wiadomości” życzenia strony polskiej, któremu w miarę możliwości mieli czynić zadośćs5.

Jeśli chodzi o brytyjskie naciski na przesunięcie polskiej jednostki, brygadier Charles Edward Dunscomb Bridge, szef brytyjskiej misji łącznikowej, na wniosek swych władz wojskowych zwrócił się do gen. Sikorskiego, ten z kolei - przed podjęciem decyzji - zlecił Raczyńskiemu zbadanie sprawy w FO. Ambasador spotkał się 2 sierpnia z parlamentarnym podsekretarzem stanu, Richardem Austenem Butlerem. Przypomniał dotychczasowe ustalenia w kwestii użycia wojsk polskich i wyraził nadzieję, że strona brytyjska nie będzie naciskać na wprowadzenie w życie wniosku bryg. Bridge'a. Ani to spotkanie, ani mająca miejsce 6 sierpnia rozmowa telefoniczna między Raczyńskim a Butlerem nie przyniosły rozstrzygnięć, ale ponownie pozwoliły dostrzec szerszy, radziecki kontekst problemu ${ }^{56}$.

Wywód przeprowadzony przez Raczyńskiego opierał się na znanych już argumentach. Ambasador mówił o sygnałach świadczących o tym, że Włosi byliby skłonni wznowić stosunki dyplomatyczne z Polakami. Rozwijając tę myśl dodawał, że rozwiązanie takie byłoby korzystne nie tylko dla Polski, ale i dla Wielkiej Brytanii, która tym sposobem uzyskałaby ,zaprzyjaźnionego agenta dyplomatycznego do kontaktów z Włochami”, a dodatkową korzyścią byłaby możliwość „zróżniczkowania stosunków Aliantów do Niemiec i Włoch”. Zwracał też uwagę na fakt, że żołnierz polski - ,z natury bitny" - nie walczyłby przeciwko Włochom tak, jak przeciwko wrogom Polski. Ten ostatni argument był przez Polaków często przywoływany. Można też dodać, że padał na podatny grunt, Brytyjczycy bowiem wysoko cenili - zwłaszcza po klęsce Francji - możliwości bojowe Polaków ${ }^{57}$.

Jeszcze bardziej istotny problem wyniknął w czasie dyskusji. Raczyński przedstawiał różne koncepcje rozwiązania sytuacji. Jako najbardziej korzystne widziałby przesunięcie Brygady Karpackiej do Anglii; zdając sobie jednak sprawę $\mathrm{z}$ trudności wprowadzenia w życie takiego rozwiązania, sugerował użycie Brygady na terenie Bliskiego Wschodu, ale nie w miejscu, gdzie starcie z Włochami

\footnotetext{
54 Ibidem. Zob. też: H. Batowski, Rozmowy dyplomatyczne..., s. 236.

55 Informacje nt. „stopniowania” próśb polskich w: „Sprawozdanie z rozmowy Ambasadora Raczyńskiego z p. Butlerem, Parlamentarnym Pod-sekretarzem Stanu w Foreign Office, odbytej w piątek, dn. 2 sierpnia 1940 r.", IPMS, PRM 20/9, zob. też PDD 1940, dok. 333.

56 Ibidem; też „Notatka z rozmowy telefonicznej Ambasadora Raczyńskiego z p. Butlerem, Parlamentarnym Pod-sekretarzem Stanu Foreign Office, dn. 6go sierpnia [1940]", IPMS, PRM 20/9. Zob. też: PDD 1940, dok. 337; „Tłomaczenie polskie listu ambasadora Raczyńskiego do Podsekretarza Stanu Butlera, [6.08.1940], IPMS, PRM 20/9. Zob. też: PDD 1940, dok. 337 (wersja angielska w TNA, FO 371/24482, C 7964/7570/55).

57 Lord Gort i sir Hugh Dowding mieli oszacować na początku lipca 1940 r., że wartość bojowa jednego Polaka równała się wartości dziesięciu Francuzów (J. Colville, The Churchillians, London 1981, s. 198). Była to jednak raczej ocena Francuzów niż Polaków.
} 
było nieuniknione. W związku z tym zaproponował skierowanie polskich wojsk do Iraku. Butler odczytał tę propozycję jako sugestię utworzenia ,straży od ściany rosyjskiej”. Raczyński natychmiast podjął tę myśl, by po raz kolejny w rozmowach z Brytyjczykami nawiązać do pogłosek o planach przekazania części GG Związkowi Radzieckiemu i uprzedzenia, że w takiej sytuacji ZSRR stałby się dla Polski takim samym wrogiem jak Niemcy. Tak zmieniona sytuacja wymagałaby brytyjskiej reakcji, zarówno na arenie międzynarodowej, jak i w stosunkach z Polską. Raczyński wspomniał w tym kontekście o reakcji USA na zajęcie Estonii, Litwy i Łotwy.

Nie po raz pierwszy więc sprawa relacji polsko-włoskich posłużyła jako pretekst do poruszenia kwestii dla Polski znacznie istotniejszej, a mianowicie stosunków ze Związkiem Radzieckim. Trzeba jednak przyznać, że sprawy włoskie zajmowały też samodzielną pozycję w myśleniu polskim. Był to czas prac rządu nad formułowaniem tez polityki zagranicznej. Kolejne wersje powstającego projektu były przedmiotem obrad Komitetu Politycznego Ministrów oraz Prezydium Rady Ministrów. Przygotowane tezy programowe rozesłane zostały polskim placówkom dyplomatycznym 15 sierpnia 1940 r. w postaci okólnika z sześcioma załącznikami. W treści zasadniczego dokumentu mowa była o tym, że ,pomiędzy Polską a Włochami nie ma stanu wojny, jest jedynie stan nieistnienia stosunków dyplomatycznych i konsularnych. Jest przedmiotem troski Rządu, aby ten stan rzeczy, będący obiektywnym odbiciem rzeczywistości politycznej pomiędzy obu społeczeństwami, nie uległ zmianie na gorsze" ${ }^{58}$. Kwestia ta rozwinięta została w załączniku nr 4, którego punkt $4 \mathrm{w}$ całości poświęcony był stanowisku wobec Włoch. Brzmiał on następująco:

Dopuszczenie do tego, aby siła zbrojna Polski miała się znaleźć w walce ze stroną włoską, jest wręcz niewskazane z uwagi na tradycyjną przyjaźń między obu narodami. Należy przeto dążyć do wycofania wojsk i jednostek polskiej marynarki wojennej z południowych teatrów wojny, lub co najmniej do uniknięcia bezpośredniej akcji przeciw Włochom. Nie trzeba wreszcie zapominać, że wydajność bojowa żołnierzy polskich w walce z Włochami byłaby znacznie mniejsza aniżeli przeciw Niemcom. Jeżeli jednak włoskie siły zbrojne morskie, lądowe lub powietrzne wzięłyby udział w bezpośrednim ataku na Wyspy Brytyjskie, uczestnictwo polskie w operacjach przeciwko Włochom będzie nieuniknione ${ }^{59}$.

Jak wiemy, cztery dni później, 19 sierpnia, Rada Ministrów przyjęła deklarację, znoszącą ograniczenia mówiące o użyciu wojsk polskich przeciw włoskim

58 PDD 1940, s. 347.

59 Sprawa polska w czasie drugiej wojny światowej na arenie międzynarodowej. Zbiór dokumentów, red. nauk. S. Stanisławska, Warszawa 1965, dok. 111, s. 177. 
tylko w przypadku zaatakowania przez te ostatnie Wysp Brytyjskich ${ }^{60}$. Koncepcja powstrzymywania się przed walką z Włochami była jednak tak silnie zakorzeniona w sposobie myślenia polskich polityków, dyplomatów i wojskowych, że Zaleski uznał za wskazane wystosować do placówek dyplomatycznych okólnik, w którym podawał argumentację, jaką można byłoby dyskretnie zastosować w poufnych rozmowach wyjaśniających przyczyny zgody na użycie Wojska Polskiego przeciw Włochom. Po raz kolejny przytaczane były słowa Mussoliniego o likwidacji Polski, wysunięty też został nowy argument, a mianowicie fakt, że ,wielu ekspertów i oficerów niemieckich jest w armii włoskiej"61.

Do zdecydowanych przeciwników użycia polskich oddziałów przeciw Włochom należał Ignacy Jan Paderewski, przewodniczący Rady Narodowej. W depeszy wystosowanej do Zaleskiego 27 sierpnia z żalem odnotowywał, że ,nie udało się przeprowadzić analogii ze stosunków Anglii do Sowietów" i dodawał, że „,[p]rzy rozprawie z Sowietami sympatia i pomoc Italii są dla nas niesłychanie ważne". Prosił również, by nie odwoływać się do słów o likwidacji Polski, ponieważ sam Mussolini się od nich odżegnał ${ }^{62}$.

Podobne stanowisko w sprawie użycia wojsk polskich przeciw Włochom zajął ambasador w Ankarze, Michał Sokolnicki. W jego ocenie wojna z Włochami nie leżała w polskim interesie, a co więcej - nie leżała w interesie brytyjskim. Ambasador był przekonany, że najkorzystniejszym rozwiązaniem byłoby oderwanie Włoch od sojuszu z Trzecią Rzeszą, a nie ich klęska. Zapowiadał, że będzie rozmawiał na ten temat z Brytyjczykami w czasie swojej wizyty w Brygadzie ${ }^{63}$. Reakcja na depeszę ambasadora była natychmiastowa. Zaleski już następnego dnia przekazał Sokolnickiemu prośbę Naczelnego Wodza, by „nie jechał do Brygady”, a równocześnie wyjaśniał, że rząd polski zdecydował przenieść Brygadę do Egiptu, a decydujące o tym były względy wojskowo-polityczne, przede wszystkim zaś „nasz stosunek do Anglii”. Dodatkowym usprawiedliwieniem podjętych decyzji miał być fakt, że polityka Włoch wobec Polski była całkowicie uzależniona od stanowiska Niemiec ${ }^{64}$.

\footnotetext{
60 W związku z tym zmieniono treść stosownego załącznika do tez polskiej polityki zagranicznej, ostatecznie uchwalonych przez Radę Ministrów 26 i 28.08.1940, zob. zał. 2 do dok. 389 w PDD 1940, s. 661.

${ }^{61} \quad$ Sprawa polska..., dok. 112, s. 178-179; zob. też PDD 1940, dok. 356, s. 603-604.

62 Sprawa polska..., dok. 114, s. 180; zob. też PDD 1940, dok. 362, s. 613-614. Paderewski pisał do Mussoliniego bezpośrednio po jego przemówieniu z 23 września. Wyrażał żal z powodu użycia określenia o likwidacji Polski. Duce był podobno pod wrażeniem tego listu i wyjaśniał, że zdanie to odnosiło się wyłącznie do klęski wojskowej Polski, a nie do jej sytuacji prawno-politycznej. Zob.: K. Strzałka, op. cit., s. 90, przyp.101.

63 M. Sokolnicki do W. Sikorskiego, 17.09.1940 - IPMS, PRM.37B, k. 174-175.

64 A. Zaleski do M. Sokolnickiego, 19.09 .1940 (podpisano do wysyłki 18.09) - ZoSIA, AAN, HI, MSZ, 800/42/0/-/224, folder 1, skan 52.
} 
Krytyczne opinie na temat polityki Włoch coraz częściej pojawiały się w wypowiedziach polskich polityków. Powstaje pytanie, na ile wywołane to było ewolucją polityki Włoch, a na ile miało służyć usprawiedliwieniu decyzji podejmowanych przez rząd RP odnośnie do walk wojsk polskich z Włochami. Wiele zdaje się wskazywać na to, że raczej ten drugi powód decydował, choć nie ulega wątpliwości, że włoska agresja na Grecję (28 października 1940) negatywnie zaważyła na polskiej opinii na temat Włoch. Silnie zaznaczało się to w wypowiedziach samego Sikorskiego, np. w czasie rozmowy, jaką przeprowadził 1 listopada 1940 r. z brytyjskim ministrem pracy, Ernestem Bevinem. Sikorski stwierdził wówczas, że „od chwili swego przyjazdu do Anglii nie przestaje doradzać Premierowi Churchillowi, by jak największą możliwie siłą lotniczą uderzył na Włochy" i dodawał, że „mając dwu przeciwników dobrze jest często atakować słabszego, w tym wypadku Włochy, by osiągnąć zwycięstwo"65. Obydwaj rozmówcy podkreślali znaczenie, jakie dla wydarzeń wojennych może mieć bombardowanie Włoch. Opinia ta rodziła się nie tylko wskutek powszechnego wówczas przekonania o roli bombardowań, ale również na podstawie zaobserwowanych już włoskich na nie reakcji ${ }^{66}$.

Te współbrzmiące ze sobą wypowiedzi Sikorskiego i Bevina nie oznaczały jednak, że poglądy polityków polskich i brytyjskich uległy ujednoliceniu. Krzysztof Strzałka stwierdza wręcz, że prezentowane przez Polaków i ich brytyjskich gospodarzy punkty widzenia na kwestię włoską były „krańcowo przeciwstawne” i wynikały z różnic w postrzeganiu roli Włoch po wojnie ${ }^{67}$. Rozbieżność ta uwidaczniała się nawet w kwestiach drugorzędnych, jak np. w trakcie przygotowań do pierwszego spotkania przedstawicieli rządów alianckich, które odbyło się 12 czerwca 1941 r. w St. James's Palace. Przyjęto wówczas rezolucję, w której deklarowano wolę kontynuowania wspólnej walki ,przeciwko niemieckiej lub włoskiej agresji aż do odniesienia zwycięstwa" 68 . Zanim tekst ten został przez stronę polską zaakceptowany, próbowano wprowadzić do niego zmiany i zastąpić sformułowanie mówiące o „niemieckiej lub włoskiej agresji” określeniem odwołującym się do „Niemiec i ich wspólników”. Zmiana taka miała przede wszystkim sprawić, by rezolucja (uchwalana jeszcze przed niemieckim atakiem na Związek Radziecki) odnosiła się również do ZSRR. Rozwiązanie takie nie zostało zaakceptowane przez Brytyjczyków, ale przystali oni na to, by Sikorski przedstawił w czasie spotkania w St. James's Palace swoje stanowisko. Polski premier wykorzystał tę sposobność,

\footnotetext{
65 PDD 1940, dok. 446, s. 757-762, tu: 757.

66 Doniesienia takie napływały już wcześniej. Zob. np.: [M.] Iżycki do W. Sikorskiego, 17.08.1940 (przesłane przez K. Dubicz-Penthera z Lizbony) - ZoSIA, AAN, HI, MSZ, 800/42/0/-/1, folder 15, skan 313, http://szukajwarchiwach.pl/800/42/0/-/1 [26.11.2011]. Pisano tam, na podstawie informacji Polaków opuszczających Włochy, że „Włosi są opanowani strachem przed bombardowaniami dochodzącym do paniki".
}

${ }^{67}$ K. Strzałka, op. cit., s. 241.

68 Sprawa polska..., s. 207. Oryginalny tekst angielski zob.: TNA, CAB 21/1379. 
by przypomnieć, że Polska jako pierwsza zbrojnie stawiła opór niemieckiej agresji, agresji, do której wkrótce przyłączyć się miał Związek Radziecki, a następnie - na innych frontach - Włochy ${ }^{69}$.

Niechęć do używania sformułowania łączącego Niemców i Włochów wiązała się nie tylko z próbą objęcia szerszym określeniem Związku Radzieckiego, ale też z próbą wprowadzenia rozróżnienia między poszczególnymi wrogimi państwami, prowadzącego do osłabienia łączących ich więzów. Ten sposób rozumowania ilustruje wypowiedź Józefa Lipskiego, który - w liście do płk. Zbigniewa Borkowskiego - pisał:

Byłem zawsze zdania, że Alianci winni działać skuteczniej w kierunku osłabiania i rozluźniania frontu państw, grupujących się w Europie przy Osi. Podstawą wszelkiej akcji w tym względzie jest - poza zwycięstwami militarnymi - prowadzenie tak elastycznej polityki, aby taktyka można była być różna w stosunku do poszczególnych państw, należących do przeciwnego obozu. Oczywiście z wyjątkiem Niemiec. [...] Dla Polski nie jest to tylko kwestia taktyki w związku z prowadzeniem wojny. Przyszłość Polski jest związana z ukształtowaniem się stosunków politycznych na kontynencie [...] Dlatego też w taktyce naszej w stosunku do państw kontynentu musimy mieć ciągle przyszłość na oku i nie zamykać żadnych drzwi, chyba że staje się to koniecznością całkiem realną w związku z prowadzeniem wojny (walka z Włochami w Libii) ${ }^{70}$.

Wspomniana konieczność walki z Włochami w Libii nie doprowadziła jednak do zaistnienia formalnego stanu wojny między obydwoma państwami, aczkolwiek wątpliwości w tej kwestii pozostały.

W styczniu 1942 r. polski ambasador w ZSRR, profesor Stanisław Kot, zwrócił się do Centrali z prośbą o informację, ,w jakiej formie nastąpiło oświadczenie Rządu Polskiego o stanie wojny z Włochami" "'1 . W odpowiedzi stwierdzano, że ponieważ Polska formalnie nie jest z Włochami w stanie wojny, więc nie było żadnego oświadczenia rządu w tej sprawie ${ }^{72}$. Kot dopytywał się jeszcze, czy w roku 1940 lub 1941 nie było żadnej deklaracji generała Sikorskiego o zaistnieniu faktycznego stanu wojny ${ }^{73}$. Nie udało się ustalić powodów tej dociekliwości, wiadomo jednak, że Edward Raczyński przytoczył w odpowiedzi fragment przemówienia

69 TNA, CAB 21/1379.

70 J. Lipski do Z. Borkowskiego, 14.02.1942 - IPMS, Kolekcja Zygmunta Borkowskiego, Kol. 4/2, k. 34-37 (tu: 34-35), http://pism.co.uk/Docs/KOL4_2.pdf [14.12.2011].

71 S. Kot do MSZ, 20.01.1942 - ZoSIA, AAN, HI, MSZ, zespół 800/42/0/-/44, folder 28, skan 1009, http://szukajwarchiwach.pl/800/42/0/-/44 [08.02.2017].

72 E. Raczyński do ambasady w Kujbyszewie, [data nieczytelna - między 21 a 31.01.1942] - ZoSIA, AAN, HI, MSZ, zespół 800/42/0/-/44, folder 28, skan 1008, http://szukajwarchiwach.pl/800/42/0//44 [ 08.02.2017].

73 S. Kot do MSZ, 31.01.1942 - ZoSIA, AAN, HI, MSZ, zespół 800/42/0/-/44, folder 28, skan 1007, http://szukajwarchiwach.pl/800/42/0/-/44 [08.02.2017]. 
Sikorskiego z 14 listopada 1940 r., w którym premier mówił o tym, że Brygada Karpacka gotowa jest walczyć również z tymi, „którzy ogłosili że Polska jest zlikwidowana definitywnie i na zawsze". Raczyński dodawał wprawdzie, że oświadczenie takie stanu wojny między Polską i Włochami nie stwarza, ale „w razie potrzeby uznać można iż istnieje taki stan de facto" 74 . Interesujące jest to przyznanie, że istnieje pewna dowolność (,,w razie potrzeby") w rozstrzyganiu o istnieniu stanu wojny między obydwoma państwami.

Takie stanowisko uwidoczniło się również w kwestii poruszonej w korespondencji między Wacławem Mohlem, pełniącym obowiązki radcy finansowego ambasady polskiej w Londynie, a Ministerstwem Spraw Zagranicznych. Mohl zwrócił się do Michała Potulickiego, radcy prawnego MSZ, w sprawie listu firmy adwokackiej „Slaughter and May”, zaangażowanej w likwidację oddziału londyńskiego Banca Commerciale Italiana. W liście tym brytyjscy prawnicy pytali, czy - i jeśli tak, to od kiedy - panuje stan wojny między Polską a Włochami. Mohl, prosząc o instrukcje, stwierdzał, że Skarb Państwa ma roszczenia wobec likwidowanego oddziału banku włoskiego na sumę 60 tys. funtów i w związku z tym „byłoby wskazane udzielić odpowiedzi, która by nie negowała istnienia stanu wojny między Polską a Italią"75. Potulicki, który sam stwierdzał, że ,[z] punktu widzenia prawa międzynarodowego stosunek nasz do Włoch jest niejasny"76, konsultował sprawę z Karolem Kraczkiewiczem, kierownikiem referatu IV (odpowiedzialnego m.in. za sprawy włoskie) dyrekcji politycznej MSZ. W rezultacie przekazano do ambasady RP w Londynie instrukcję, zgodnie z którą nie powinna się wypowiadać w prawnej kwestii stanu wojny, a jedynie przedstawić argumenty, ,z których czynniki angielskie mogłyby wysnuć wniosek, że pomiędzy Polską a Włochami istnieje taki stan faktycznie". Obawiano się, że pisemne stwierdzenie, iż Polska jest w stanie wojny z Włochami mogłoby później zostać wykorzystane ,wbrew naszym zamiarom a w każdym razie wymagałoby zasadniczej decyzji”. Wśród argumentów, na które należało się powołać, przywoływano fakt zerwania przez Włochy stosunków dyplomatycznych z Polską ,w chwili, gdy nastąpił stan wojny pomiędzy Włochami Anglią i Francją", internowanie obywateli polskich na terenie Włoch oraz to, że wojska polskie w Libii ,walczą czynnie z armją niemiecką i włoską"77. Zwraca tu uwagę podkreślanie związku między działaniami włoskimi i niemieckimi.

74 E. Raczyński do ambasady w Kujbyszewie, 10.02.1942 - ZoSIA, AAN, HI, MSZ, zespół 800/42/0/-/44, folder 28, skan 1006, http://szukajwarchiwach.pl/800/42/0/-/44, dostęp 8.02.2017.

75 W. Mohl do M. Potulickiego, 20.11.1941 - ZoSIA, AAN, HI, MSZ, zespół 800/42/0/-/44, folder 28, skan 1003, http://szukajwarchiwach.pl/800/42/0/-/44, dostęp 8.02.2017. List „Slaughter and May" do W. Mohla, 10.09.1941; ibidem, skan 1004.

76 Odręczna notatka M. Potulickiego na liście W. Mohla z 20.11.1941 - jak w przyp. 75.

77 Sekretarz Generalny MSZ do ambasady RP w Londynie, 24.11.1941, tajne - ZoSIA, AAN, HI, MSZ, zespół 800/42/0/-/44, folder 28, skany 999-1000, http://szukajwarchiwach.pl/800/42/0/-/4 [08.02.2017]. 
Zaprezentowane stanowisko nie rozwiązało sprawy. Mohl zwrócił uwagę na to, że pytanie firmy "Slaughter and May” dotyczyło nie tylko samego faktu istnienia stanu wojny, ale również daty jego rozpoczęcia ${ }^{78}$. Ujawniło to kolejne wątpliwości w MSZ. Potulicki pisał, że najwygodniejsze byłoby określenie początku faktycznego stanu wojny na rozpoczęcie działań wojennych w Libii. Umiejscowienie daty początkowej w tym okresie uważał za ,politycznie wygodn[e]”, ze względu na ówczesne działania Afrika Korps w tym rejonie. Wyrażał równocześnie wątpliwości, czy data taka nie byłaby zbyt późna z punktu widzenia polskich interesów w procesie o likwidację oddziału włoskiego banku. Sugerował też powołanie się na wystąpienie gen. Sikorskiego z 14 listopada 1940 r. (była o nim mowa wyżej) ${ }^{79}$. W rezultacie w MSZ przygotowana została formuła odpowiedzi, jakiej Mohl udzielić miał firmie „Slaughter and May”. Nie podawano w niej konkretnej daty rozpoczęcia faktycznego stanu wojny, sugerowano jednak, że najbardziej odpowiednie byłoby wskazanie na marzec 1941 r., czyli czas kiedy w Cyrenajce pojawiły się wojska niemieckie, w związku z czym wojska polskie ,mogły [podkr. moje - MH] każdej chwili znaleźć się w akcji przeciwko oddziałom niemieckim, a równocześnie przeciw ich sprzymierzeńcom włoskim" ${ }^{80}$. W rzeczywistości o pierwszych starciach zbrojnych polsko-włoskich można mówić dopiero od 22 sierpnia 1941 r., kiedy oddziały polskie zajęły stanowiska w Tobruku.

Powyższe rozważania wskazują na brak jednolitej, rozstrzygającej wykładni w sprawie istnienia bądź nieistnienia stanu wojny między Polską i Włochami w 1940 r., jak również później, w okresie kiedy Wojsko Polskie weszło już w kontakt zbrojny z siłami włoskimi.

\section{Enemies of our allies. The issue of (non) existence of war between Poland and Italy. 1940}

\section{Summary}

The article presents the Polish government's attitude to the issue of participation of Poland in the war against Italy. On the one hand, it was affected by direct Polish interests, which required the policy of restraint (moderation) without getting involved in this conflict and, on the other hand, by Poland's obligations as an ally

\footnotetext{
78 W. Mohl do MSZ, 8.12.1941 - ZoSIA, AAN, HI, MSZ, zespół 800/42/0/-/44, folder 28, skan 998, http://szukajwarchiwach.pl/800/42/0/-/44 [08.02.2017].

79 M. Potulicki do K. Kraczkiewicza, 12.12.1941, tajne - ZoSIA, AAN, HI, MSZ, zespół 800/42/0/144, folder 28, skan 996-997, http://szukajwarchiwach.pl/800/42/0/-/44 [08.02.2017].

80 Sekretarz Generalny MSZ (K. Morawski) do W. Mohla, 9.01 .1942 wraz z zał. - ZoSIA, AAN, HI, MSZ, zespół 800/42/0/-/44, folder 28, skany 990-991, http://szukajwarchiwach.pl/800/42/0/-/44 [08.02.2017].
} 
of France and Great Britain, which were at war against Italy since $10^{\text {th }}$ June, 1940. This problem became particularly acute when likelihood of a potential military conflict between Polish and Italian forces increased due to the deployment of Carpathian Rifle Brigade first to Palestine and then to Egypt. In result of the conviction that maintenance of political compliance between Poland and Great Britain was a supreme objective, on $19^{\text {th }}$ August 1940 Polish government agreed to use Polish forces against the Italian army. Nevertheless, this consent did not entail that Poland declared war against Italy. Polish government claimed that it was exempted from such a decision because after $17^{\text {th }}$ September 1939, French and British governments did not declare war against the Soviet Union against which Poland, in turn, was at war. Although the analogy invoked by the Polish government was debatable, it provided a possibility of reminding the British ally that Poland was also a victim of Soviet expansion in the face of increasingly intensive critique of the USSR after the annexation of Baltic States, Bessarabia and Northern Bucovina.

The article has been mostly based on resource materials. Documents of the Polish Ministry of Foreign Affairs from the Hoover Institute collection, whose microfilms were handed over to the Central Archives of Modern Records and then made available online in the Integrated Archive System, were particularly important. Documents from the Polish Institute and Sikorski Museum in London were also used herein and, additionally, documents from the British National Archives. A query in Italian archives was not carried out for the needs of this article; yet published Italian documents were used herein.

Key words: Polish government in exile, Italy, diplomatic relations, state of war

\section{Bibliografia}

\section{Źródła archiwalne}

Archiwum Akt Nowych, Warszawa.

Ministerstwo Spraw Zagranicznych (800/42/0).

Poselstwo w Bernie (2/495/0).

Instytut Polski i Muzeum im. Generała Sikorskiego, Londyn.

Rada Narodowa (A.5).

Ambasada R.P. w Londynie (A.12).

Prezydium Rady Ministrów (PRM).

Kolekcja Zygmunta Borkowskiego (Kol. 4).

The National Archives, Kew.

Foreign Office. General Correspondence (FO 371).

Foreign Office. Confidential Print (FO 417).

Cabinet Office [..] Registered Files (CAB 21). 


\section{Źródła publikowane}

Ciano's Diplomatic Papers, red. M. Muggeridge, przeł. S. Hood, London 1948.

[I] Documenti diplomatici italiani. Serie 9 (1939-1943), t. 1-7, Roma 1954-1987.

Documenti - Documenti per la storia delle relazioni italo-polacche (1918-1940). Dokum menty dotyczqce historii stosunków polsko-wtoskich (1918-1940 r.), a cura di oprac. przez: M. Di Simone, N. Eramo, A. Fiori, J. Stoch, t. II, [Roma] 1998.

Documents on Soviet-Polish Relations, 1939-1945, t. 1: [1939-1943], London 1961.

Dzienniki czynności Prezydenta RP Władysława Raczkiewicza. 1939-1947, t. I: 1939 1942, oprac. J. Piotrowski, Wrocław 2004.

Polskie Dokumenty Dyplomatyczne. 1939 wrzesień-grudzień, red.: W. Rojek, współpr.: P. Długołęcki, M. Konopka-Wichrowska, M. Przyłuska, Warszawa 2007.

Polskie Dokumenty Dyplomatyczne. 1940, red. M. Hułas, Warszawa 2010.

Polskie Dokumenty Dyplomatyczne. 1941, red. J. Tebinka, Warszawa 2013.

Protokoły z posiedzeń Rady Ministrów Rzeczypospolitej Polskiej, t. I: październik 1939 czerwiec 1940, oprac. W. Rojek, współpr. A. Suchcitz, Kraków 1994.

Protokoły posiedzeń Rady Ministrów Rzeczypospolitej Polskiej, t. II: czerwiec 1940 czerwiec 1941, red. nauk. M. Zgórniak, oprac. W. Rojek, współpr. A. Suchcitz, Kraków 1995.

Sprawa polska w czasie drugiej wojny światowej na arenie międzynarodowej. Zbiór dokumentów, red. nauk. S. Stanisławska, Warszawa 1965.

\section{Wspomnienia i dzienniki}

Ciano G., Dziennik. 1937-1943, tłumaczenie i opracowanie naukowe T. Wituch, Pułtusk 2006.

Colville J., The Churchillians, London 1981.

Kopański S., Wspomnienia wojenne 1939-1946, Londyn b.d.w.

Romeyko M., Wspomnienia o Wieniawie i o rzymskich czasach, Warszawa 1990.

Szembek J., Diariusz, wrzesień - grudzień 1939, przedmowę napisał i przypisami opatrzył B. Grzeloński, Warszawa 1989.

\section{Opracowania}

Batowski H., Rozmowy dyplomatyczne wokół Brygady Karpackiej latem 1940 roku, „Wojskowy Przegląd Historyczny" 1981, nr 4, s. 231-240.

Batowski H., Walka dyplomacji hitlerowskiej przeciw Polsce. 1939-1945, Kraków, Wrocław 1984.

Batowski H., Z dziejów dyplomacji polskiej na obczyźnie (wrzesień 1939 - lipiec 1941), Kraków, Wrocław 1984. 
Łojek J. (L. Jerzewski), Agresja 17 września 1939. Studium aspektów politycznych, Warszawa 1990.

Marek K., Identity and Continuity of States in Public International Law, Genève 1954.

Sierpowski S., Stosunki polsko-włoskie w latach 1918-1940, Warszawa 1975.

Sierpowski S., Italy and the Nazi Aggression on Poland in 1939, „Polish Western Affairs” 1978, t. 19, nr 1, s. 34-57.

Sobczak J., Polska w propagandzie i polityce III Rzeszy w latach 1939-1945, Poznań 1988.

Strzałka K., Między przyjaźniq a wrogościq. Z dziejów stosunków polsko-włoskich (1939_ 1945), Kraków 2001.

Tebinka J., Churchill i Sikorski. Koncepcje wykorzystania Polskich Sił Zbrojnych w latach 1940-1941, [w:] Samodzielna Brygada Strzelców Karpackich w obronie Tobruku, red. nauk. J. Zuziak, Warszawa 2016, s. 123-136.

Tebinka J., „Wielka Brytania dotrzyma lojalnie swojego słowa”. Winston S. Churchill a Polska, Warszawa 2013.

Wandycz P., Z Pitsudskim i Sikorskim. August Zaleski, minister spraw zagranicznych w latach 1926-1932 i 1939-1941, Warszawa 1999. 